\title{
Immunohistochemical Localization and Characterization of Putative Mesenchymal Stem Cell Markers in the Retinal Capillary Network of Rodents
}

\author{
Dierk Wittig $^{\mathrm{a}}$ József Jászai ${ }^{\mathrm{a}}$ Denis Corbeil ${ }^{\mathrm{b}, \mathrm{c}}$ Richard H.W. Funk ${ }^{\mathrm{a}, \mathrm{c}}$ \\ ${ }^{a}$ Institute of Anatomy, ${ }^{b}$ Tissue Engineering Laboratories, Biotechnology Center (BIOTEC), and ${ }^{\mathrm{C} D F G}$ Research Center \\ and Cluster of Excellence for Regenerative Therapies, TU Dresden, Dresden, Germany
}

\section{Key Words}

Capillary network · CD146 · Mesenchymal stem cell markers $\cdot$ NG2 $\cdot$ Pericytes $\cdot$ Retinal vascular plexus

\begin{abstract}
Perivascular cells of microvascular niches are the prime candidates for being a reservoire of mesenchymal stem cell (MSC)-like cells in many tissues and organs that could serve as a potential source of cells and a target of novel cell-based therapeutic approaches. In the present study, by utilising typical markers of pericytes (neuronal-glial antigen 2, NG2, a chondroitin sulphate proteoglycan) and those of MSCs (CD146 and CD105) and primitive pluripotent cells (sex-determining region Y-box 2, Sox2), the phenotypic traits and the distribution of murine and rat retinal perivascular cells were investigated in situ. Our findings indicate that retinal microvessels of juvenile rodents are highly covered by NG2positive branching processes of pericytic (perivascular) cells that are less prominent in mature capillary networks of the adult retina. In the adult rodent retinal vascular bed, NG2 labeling is mainly confined to membranes of the cell body re-
\end{abstract}

D.W. and J.J. contributed equally to this work, therefore both authors should be considered as first authors.

\section{KARGER}

E-Mail karger@karger.com

www.karger.com/cto

sulting in a pearl-chain-like distribution along the vessels. Retinal pericytes, which were identified by their morphology and NG2 expression, simultaneously express CD146. Furthermore, CD146-positive cells located at small arteriole-tocapillary branching points appear more intensely stained than elsewhere. Evidence for a differential expression of the two markers around capillaries that would hint at a clonal heterogeneity among pericytic cells, however, is lacking. In contrast, the expression of CD105 is exclusively restricted to

\section{Abbreviations used in this paper}

CD105

CD146

DAPI

DIC

IHC

MSC

NG2

$\mathrm{P}$

PBS

PBSTX-0.1\%

PFA

RT

Sox 2

\author{
SH2; endoglin - TGF $\beta$ co-receptor \\ MCAM/MUC18/S-Endo1 \\ 4,6-diamidino-2-phenylindole \\ differential interference contrast \\ immunohistochemistry \\ mesenchymal stem cell \\ neuron-glial antigen 2 \\ postnatal day \\ phospate-buffered saline \\ PBS + 0.1\% Triton X-100 \\ paraformaldehyde \\ room temperature \\ sex-determining region Y-box 2
}


vascular endothelial cells and Sox2 is detected neither in perivascular nor in endothelial cells. In dissociated retinal cultures, however, simultaneous expression of NG2 and CD105 was observed. Collectively, our data indicate that vascular wall resident retinal pericytes share some phenotypic features (i.e. CD146 expression) with archetypal MSCs, which is even more striking in dissociated retinal cultures (i.e. CD105 expression). These findings might have implications for the treatment of retinal pathologies.

Copyright $\odot 2013$ S. Karger AG, Basel

\section{Introduction}

Mural (perivascular) cells, including pericytes, support the maintenance of vessel stability and inhibit endothelial cell proliferation [Gerhardt and Betsholtz, 2003]. These cells are also involved in the regulation of vascular tone in the brain [Peppiatt et al., 2006] and in the retina [Funk, 1997; Schonfelder et al., 1998].

The degree of microvessel coverage shows a significant difference in various organs [Sims, 1991; Funk, 1997]. Retinal capillaries typically have a greater pericyte/endothelial cell ratio (up to 1:1) than capillaries in many other organs (e.g. skeletal muscle, 1:100) [Cogan and Kuwabara, 1967; Tilton et al., 1985; Stewart and Tuor, 1994; Ejaz et al., 2008]. In comparison to capillaries in other organs, retinal capillaries are very thin and form a relatively sparse network [Funk, 1986, 1997]. The distribution and morphology of pericytes along pre-, mid- and postcapillary microvascular segments considerably differs within a particular organ. Pericytes along pre- and postcapillary segments with contractile properties are characterised by the expression of a smooth muscle isoform of $\alpha$-actin representing gradual transitions toward the smooth muscle phenotype [Nehls and Drenckhahn, 1991; Diaz-Flores et al., 2009a]. Under various pathological conditions, the pericytic coverage of microvessels changes dramatically. It is well documented in diabetic retinopathy that the significant loss of pericytes [Cogan and Kuwabara, 1967] triggers further (secondary) vascular and neurodegenerative symptoms in the retina [Feit-Leichman et al., 2005; Hammes, 2005; Ikesugi et al., 2006; Ejaz et al., 2008; Schmidt et al., 2008]. The role of pericytes in brain pathology also attracts significant attention since the number of perivascular cells around cerebral microvessels is fourfold increased in spontaneously hypertensive rats in comparison to normotensive animals [Hirschi and D'Amore, 1996]. Moreover, the significance of pericyte loss in conjunction with the onset and pathogenesis of certain neu- rodegenerative diseases is the subject of recent investigations [Verbeek et al., 1997, 1999; Zlokovic, 2008].

Recently, the existence of a 'vascular niche' was revealed in the wall of arteries and microvessels in different organs. At this location, a small fraction of cells was found with characteristics for multipotent cells, e.g. mesenchymal stem cells (MSCs). In larger arteries in many organs, this niche appears to be confined to the adventitia and to a narrow subendothelial zone of the muscular media [Til$\mathrm{ki}$ et al., 2009]. Interestingly, isolated mural cells of microvessels, which are endowed with MSC-like traits, are also capable of multilineage differentiation [Covas et al., 2008]. Altogether these data suggest that 'pericytes' comprise rather a heterogeneous class of cells situated outside the endothelial layer in capillaries that may harbor a fraction of MSC-like cells [Diaz-Flores et al., 2009b]. This has been demonstrated among others for capillaries in the brain [Kang et al., 2010] and in the dental pulp [Feng et al., 2011]. Moreover, pericytes reminiscent of MSCs secrete a complex combination of growth factors and cytokines [Witmer et al., 2004; Chen et al., 2009; Thanabalasundaram et al., 2010]. Thus, pericytes in general as well as those around retinal vessels might represent a potential source of cells for tissue protection and immunomodulation in addition to a plausible application for tissue repair and regeneration.

To establish a framework for future comparative and functional studies, we have analyzed the phenotypic features and development-related changes in pericytes in the murine and rat retina. By utilising typical markers of pericytes and MSCs, we have addressed the question of whether the molecular signatures (phenotypic traits) characteristic of MSCs can be found in pericytes of retinal microvessels in situ, and we compared the distribution of these retinal perivascular cells in animals on postnatal day (P) 14 and in adult animals.

\section{Materials and Methods}

\section{Tissue Samples}

Rat and murine retinae were investigated at the end of the 2nd postnatal week shortly after the release of the fusion of the eyelids and in young adult animals. All animal procedures were performed in compliance with the UK Animals Act (Scientific Procedures) 1986 and local ethics committee guidelines. Animals for organ removal were euthanized according to the Code of Practice entitled: The Humane Killing of Animals under Schedule 1 to the Animals (Scientific Procedures) Act 1986.

Adult and postnatal mouse retinal samples were obtained from the NMRI strain. Mice were deeply anesthetised by a single intraperitoneal bolus injection of ketamine and xylazine followed by a 
quick transcardial perfusion with ice-cold $4 \%$ paraformaldehyde (PFA). Eyes were removed from the orbits and postfixed in $4 \%$ PFA at $4^{\circ} \mathrm{C}$ and then rinsed in phosphate-buffered saline (PBS); retinae were isolated by microdissection. Briefly, a circumferential incision was made by iris scissors at the corneoscleral border, and the anterior segment of the eye with the lens and the vitreous body were removed. The remaining posterior eyecup was further dissected with fine-tip watchmaker's forceps and the retina was freed from choroidea and sclera. Isolated retinae were washed with icecold PBS and further processed for whole-mount immunocytochemistry. In some cases, eyes were cryoprotected with $30 \%$ sucrose-PBS, embedded in OCT compound (Tissue-Tek, Sakura, The Netherlands) and $14-\mu \mathrm{m}$ cryosections were mounted onto SuperFrost ${ }^{\circledR}$ Plus microscope slides (Menzel-Gläser, Braunschweig, Germany). Sections were further processed for immunocytochemistry.

Retinal samples were obtained from adult and postnatal Wistar rats. After euthanasia by overexposure to $\mathrm{CO}_{2}$, the eyes were quickly removed from the orbits and transferred into ice-cold PBS. The eyes were immediately microdissected as described above. The isolated retinae were flattened and immersion fixed in $4 \%$ PFA at $4^{\circ} \mathrm{C}$. Retinae were then rinsed in PBS and further processed for wholemount immunocytochemistry.

Primary Culture of Plastic-Adherent Dissociated Perivascular Cells of the Murine Retina

Primary cultures of dissociated retinae were prepared as previously described [Scheef et al., 2009; Tigges et al., 2012] from adult mice by pooling tissue from littermates. Retinas were rinsed with ice-cold Hanks' balanced salt solution and were pooled in an Eppendorf tube followed by digestion with papain solution (Papain dissociation system, LK003150, Worthington, Lakewood, N.J., USA) for $45 \mathrm{~min}$ at $37^{\circ} \mathrm{C}$. Cellular digests were then transferred to a reaction tube containing $60 \mu \mathrm{l} / \mathrm{ml}$ of DNase I, $1 \mathrm{ml}$ of ovomucoid solution and $520 \mu \mathrm{l}$ of Earle's balanced salt solution according to the manufacturer's description. Cells were triturated by four gentle up/down strokes with a fire-polished Pasteur pipette. The dissociated cells were pelleted in a centrifuge at $300 \mathrm{~g}$, then the pellet was resuspended in Dulbecco's modified Eagle's medium supplemented with $10 \%$ fetal bovine serum plus $1 \%$ antibiotics (penicillin/ streptomycin). The cell suspension $\left(1 \times 10^{6}\right.$ cells $\left./ \mathrm{ml}\right)$ was plated on a 35-mm, low-wall, plastic $\mu$-Dish (Ibidi, Munich, Germany); 100 $\mu \mathrm{l} /$ dish were plated and cultured in a humidified incubator in $5 \%$ $\mathrm{CO}_{2}$ at $37^{\circ} \mathrm{C}$. After plating, cells were allowed to adhere for $4 \mathrm{~h}$, and the plating medium was removed and replaced with $500 \mu \mathrm{l}$ of fresh culture media. Non-adherent cells, cell debris and undigested clumps were removed by changing media after the initial 24-hour culture period. Thereafter, media were changed every 3 rd day (total incubation period: 3 weeks).

Whole-Mount Immunocytochemistry on Isolated Retinae

Isolated retinal sheets were rinsed with PBS and washed in PBSTX-0.1\% (PBS + 0.1\% Triton X-100) twice for $10 \mathrm{~min}$ at room temperature (RT). Tissues were permeabilised by changes of PBSTX-1\% for 15 min each followed by three changes of PBSTX-0.1\% for 10 min each. Unspecific antibody binding was blocked by incubating samples with blocking solution (PBSTX- $0.1 \%$ containing $10 \%$ normal goat serum) for $1 \mathrm{~h}$ at RT. Murine and rat samples were then reacted with anti-neuron-glial antigen 2 (NG2) chondroitin sulphate proteoglycan (1:400; rabbit;
Millipore, Temecula, Calif., USA, and 1:200; mouse; LifeSpan BioSciences, Seattle, Wash., USA, respectively), either alone or in combination with additional primary antibodies. These were either anti-CD146 (alias MCAM/MUC18/S-Endo1; 1:200; rat; Miltenyi Biotech, Bergisch Gladbach, Germany) or anti-CD105 (alias SH2; endoglin-TGF $\beta$ coreceptor; 1:200; rat; Miltenyi Biotech) for murine samples and anti-CD146 (1:100; rabbit; Epitomics Inc., Burlingame, Calif., USA) or anti-CD105 (endoglin; 1:100; mouse; Acris Antibodies, Herford, Germany) for rat samples. All antibodies were diluted in blocking solution and incubated overnight at $4^{\circ} \mathrm{C}$. Samples were then washed with three changes of PBSTX- $0.1 \%$ for 10 min each at RT. Primary antibodies were detected using appropriate fluorochrome-conjugated secondary antibodies as follows: goat anti-rabbit Alexa-546, goat anti-mouse Alexa-546, goat anti-mouse Alexa-488, goat anti-rabbit Alexa-488 and goat anti-rat Alexa-488 (1:1,000; Molecular Probes, Eugene, Oreg., USA) diluted in blocking solution for $1 \mathrm{~h}$ at RT. Samples were then washed with three changes of PBSTX-0.1\% for 10 min each followed by three washes in PBS rinsed once with PBS. In order to facilitate the identification of nuclei, in some cases samples were counterstained with 4,6-diamidino-2-phenylindole (DAPI; $1 \mu \mathrm{g} / \mathrm{ml}$; Molecular Probes). After washing once with PBS, retinal samples were flat mounted with the ganglion cell layer being up using PBS-glycerol (2:1).

\section{Immunohistochemistry of Cryosections}

Immunohistochemistry (IHC) was performed on serial cryostat sections as described previously [Jaszai et al., 2010]. Briefly, sections were labelled with mouse monoclonal antibody 2018 against the human sex-determining region Y-box (Sox) 2 (1:200; R\&D Systems, Minneapolis, Minn., USA) followed by an Alexa488-conjugated goat anti-mouse IgG2a isotype-specific secondary antibody $(1: 1,000)$. Sections were counterstained with DAPI $(1 \mu \mathrm{g} /$ $\mathrm{ml})$. After washing once with PBS, slides were mounted with Mowiol 4.88 (Calbiochem, San Diego, Calif., USA).

\section{Microscopy}

Stained retinal samples were analyzed by epifluorescence. Images were captured using an Olympus BX61 microscope with the IPLAB software. Composite images were prepared from the digital data files using Adobe Photoshop and Illustrator software (San Jose, Calif., USA).

\section{Results}

In order to characterise rodent retinal pericytes, we have performed an IHC analysis using established markers of pericytes, MSCs and other stem and progenitor cells. Murine and rat retinal whole-mount samples were analyzed from adults as well as from juveniles at the end of the 2nd postnatal week (P14) shortly after the release of the eyelid fusion.

\section{Distribution of Pericytes along Juvenile and Adult \\ Retinal Microvessels of Rodents}

As a starting point of the study, we have investigated the overall morphology (branching patterns) of vessels in 
Fig. 1. Mural (perivascular) cells in retinal capillary networks. Retinal flat mounts of an adult rat, either unstained $(\mathbf{a}, \mathbf{c})$ or after anti-NG2 IHC (b), were observed with DIC (Nomarski) optics to visualise the superficial layer of the retinal vascular plexus. a, c Retina whole-mount DIC images show pericytes (white arrowheads) in comparison to endothelial cells (white hollow arrowheads). b Merged image of Nomarski and epifluorescence captures depicting the position of NG-2-reactive perivascular cells (red fluorescence, white arrowheads). a-c The abluminal, prominent nuclei (white arrowhead) aligned along endothelial tubes readily identify pericytic cells covering retinal vessels that are easily discernible from the nuclei of endothelial cells (white hollow arrowheads). Pericytes are often observed also at vessel branching points (white arrows; c). White asterisks label intervascular fields. Scale bars $=20 \mu \mathrm{m}$.
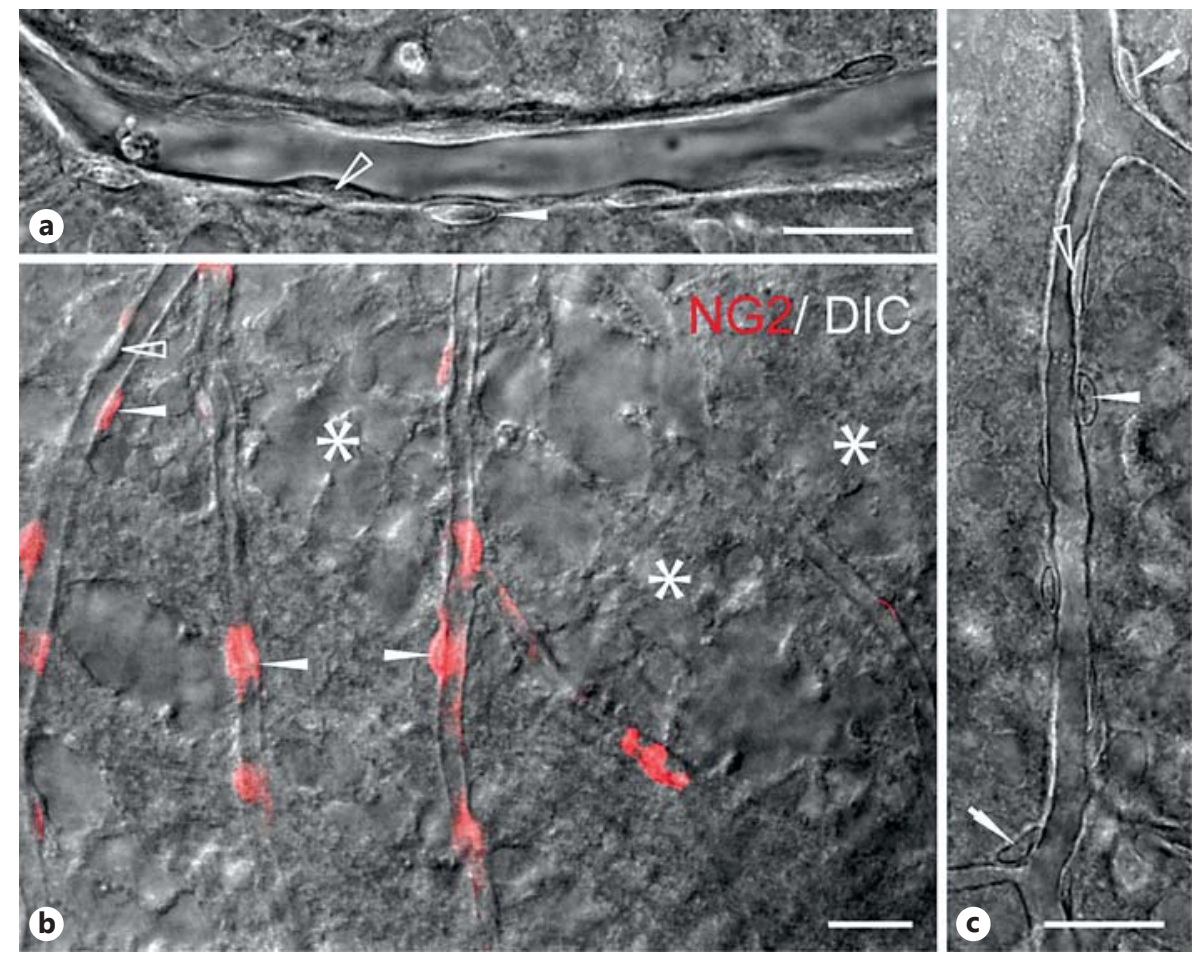

the superficial retinal vascular plexus overlying the ganglion cell layer. The vascular network was identified by means of differential interference contrast (DIC) microscopy in isolated rat retinal sheets mounted with the ganglion cell layer being upwards (fig. 1). Vessels of the superficial plexus showed a typical branching pattern with rather large capillary-free zones (fig. 1b; white asterisks) characteristic of the adult retina. Vessel walls under these conditions were clearly visible with the endothelial cell nuclei bulging into the capillary lumen (fig. 1a-c; white hollow arrowheads). In close association with the endothelial tube, prominent nuclei of pericytic cells were also visible as abluminal bulges surrounded by a narrow cytoplasm (fig. 1a-c; white arrowheads). These cells were also readily identified by the expression of NG2 proteoglycan (also known as high-molecular-weight melanoma-associated antigen; fig. $1 \mathrm{~b}$; red fluorescence), a molecule exclusively expressed by perivascular (mural) cells during vascular morphogenesis [Ozerdem et al., 2002]. Pericytes accompanied not only the straight segments of the capillary bed but were also often observed at branching points of the endothelial tube (white arrows; fig. 1c).

Next, we have analyzed the distribution of pericytes in retinal whole-mount preparations by IHC detection of NG2. In the first set of staining, we analyzed the distribu- tion of NG2-positive cells in P14 mice and rats. As already known, by P14, the superficial layer of the retinal vascular plexus had already reached the edge of the rodent retina [Benjamin et al., 1998], and the superficial vascular plexus formed a dense network with relatively small capillaryfree areas (fig. 2a, c, fig. 3a; online supplementary fig. 1a; for all online supplementary material, see www. karger.com/doi/10.1159/000346661). The endothelial tubes of this network were tightly covered with processes of NG2-positive cells in both rodent species (fig. 2a, $\mathrm{a}^{\prime}, \mathrm{c}$, fig. 3a, c, c'; white arrowheads).

In the next set of staining, the capillary network of adult retinae was analyzed by the same method (fig. $2 \mathrm{~b}$, $b^{\prime}$, d, fig. 3b, d, d'). The adult stages were characterised by a reduction in overall vascular density resulting in somewhat larger capillary-free areas (fig. 3; online suppl. fig. 1b). More importantly, NG2 reactivity was rather concentrated in perinuclear domains of perivascular cells (white arrowhead in online suppl. fig. 2a, b; online suppl. movie, 3D reconstruction) appearing as spots of greater distance aligned along the endothelial tube resulting in a relative sparse pericytic coverage (fig. 2, 3; please compare fig. $2 a^{\prime}$ and $b^{\prime}$, and fig. $3 c$ and d, respectively). 

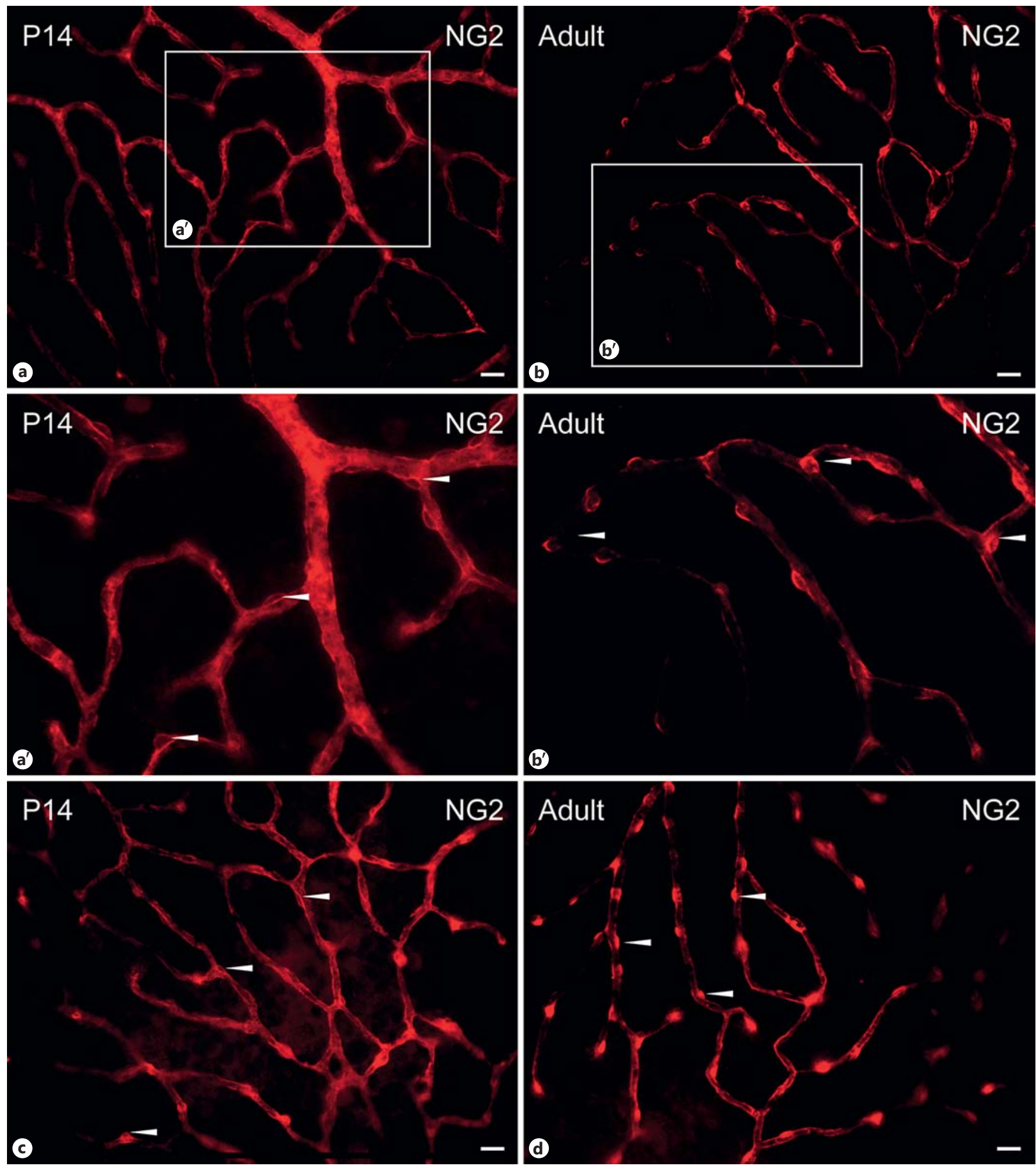

Fig. 2. In situ architecture of retinal vessels of adult and P14 rat retinae. Retinal cups isolated from 2 -week-old $\left(\mathbf{a}, \mathbf{a}^{\prime}, \mathbf{c}\right)$ and adult (b, $\left.\mathbf{b}^{\prime}, \mathbf{d}\right)$ rats were subjected to IHC detection of NG2 (red fluorescence) and compared in whole mounts. The boxed areas $(\mathbf{a}, \mathbf{b})$ are displayed at a higher magnification ( $\mathbf{a}^{\prime}$ and $\mathbf{b}^{\prime}$, respectively). $\mathbf{a} / \mathbf{c}$,

b/d Overview images of the superficial capillary meshwork in the retina of P14 and adult rat, respectively. $\mathbf{a}^{\prime}-\mathbf{d}$ White arrowheads indicate pericytic cells accompanying the vascular bed. $\mathbf{a}^{\prime}, \mathbf{b}^{\prime}$ Note that in the P14 rat retina NG2 labelling (red fluorescence) is more evenly spread along the vessels than in the adult retina. Scale bars $=20 \mu \mathrm{m}$. 

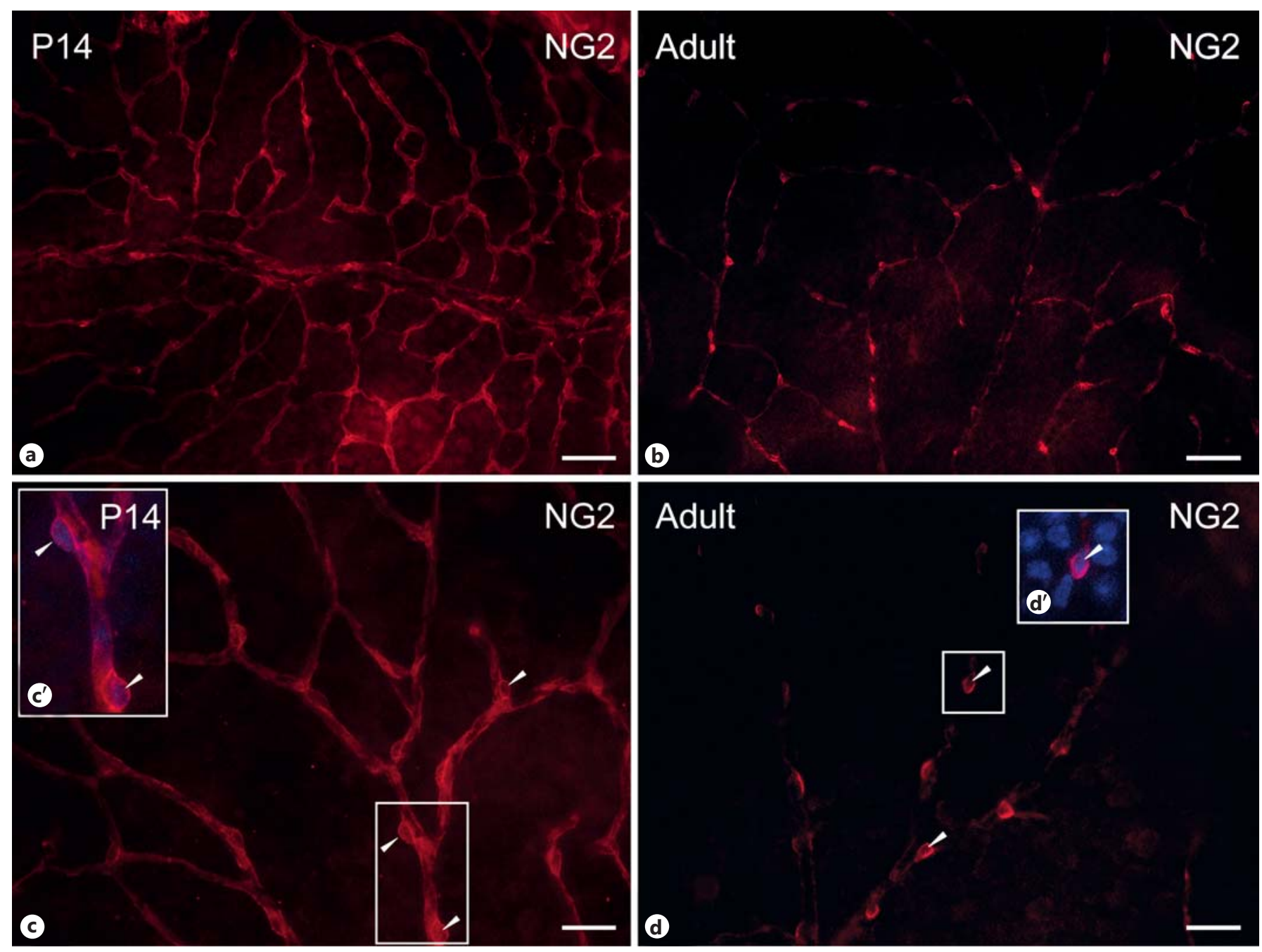

Fig. 3. In situ architecture of retinal vessels of adult and P14 murine retinae. Retinal cups isolated from 2 -week-old $\left(\mathbf{a}-\mathbf{c}^{\prime}\right)$ and adult ( $\mathbf{b}-$ d') mice were subjected to IHC detection of NG2 (red fluorescence) and compared in whole mounts. $\mathbf{a}, \mathbf{b}$ Overview images of the superficial capillary meshwork in the retina of P14 and adult mice, respectively. Note that in P14 murine retina (a), vascular density is somewhat higher than in the adult retina (b). c, d Higher magnification of P14 and adult capillary networks. c-d' White

arrowheads indicate NG2-positive perivascular cells. The boxed areas $(\mathbf{c}, \mathbf{d})$ are displayed as zoom-in insets with DAPI counterstaining in order to visualise cell nuclei. a-d White arrowheads indicate pericytic cells accompanying the vascular bed. c, d Note that in the P14 murine retina, NG2 labeling (red fluorescence) covers larger portions of capillary vessels than in the adult retina. Scale bars $=50(\mathbf{a}, \mathbf{b})$ and $25 \mu \mathrm{m}(\mathbf{c}, \mathbf{d})$.

In situ Expression of the MSC Marker CD146 by

Rodent Retinal Pericytes

Next, we have addressed whether expression of CD146, a cell surface marker extensively used for prospective isolation of MSCs [Sacchetti et al., 2007; Sorrentino et al., 2008], could identify perivascular cells in rodent retinal whole-mount sheets. In mice, expression of CD146 was revealed by a well-characterised monoclonal antibody (ME-9F1) specifically recognising murine CD146 [Schrage

et al., 2008], while in the rat an anti-CD146 rabbit monoclonal antibody was used that was previously characterised [Anfosso et al., 2001]. The samples were simultaneously co-labelled for NG2 in order to highlight pericytic cells. The overall distribution of CD146 reactivity matched that of NG2 both in juvenile (please compare fig. 4a and $\mathrm{b}$, white arrowheads) and adult (fig. $4 \mathrm{c}$ and $\mathrm{d}$, white arrowheads; merged image) murine retinal samples. It was interesting to note that in adult murine samples the stain- 


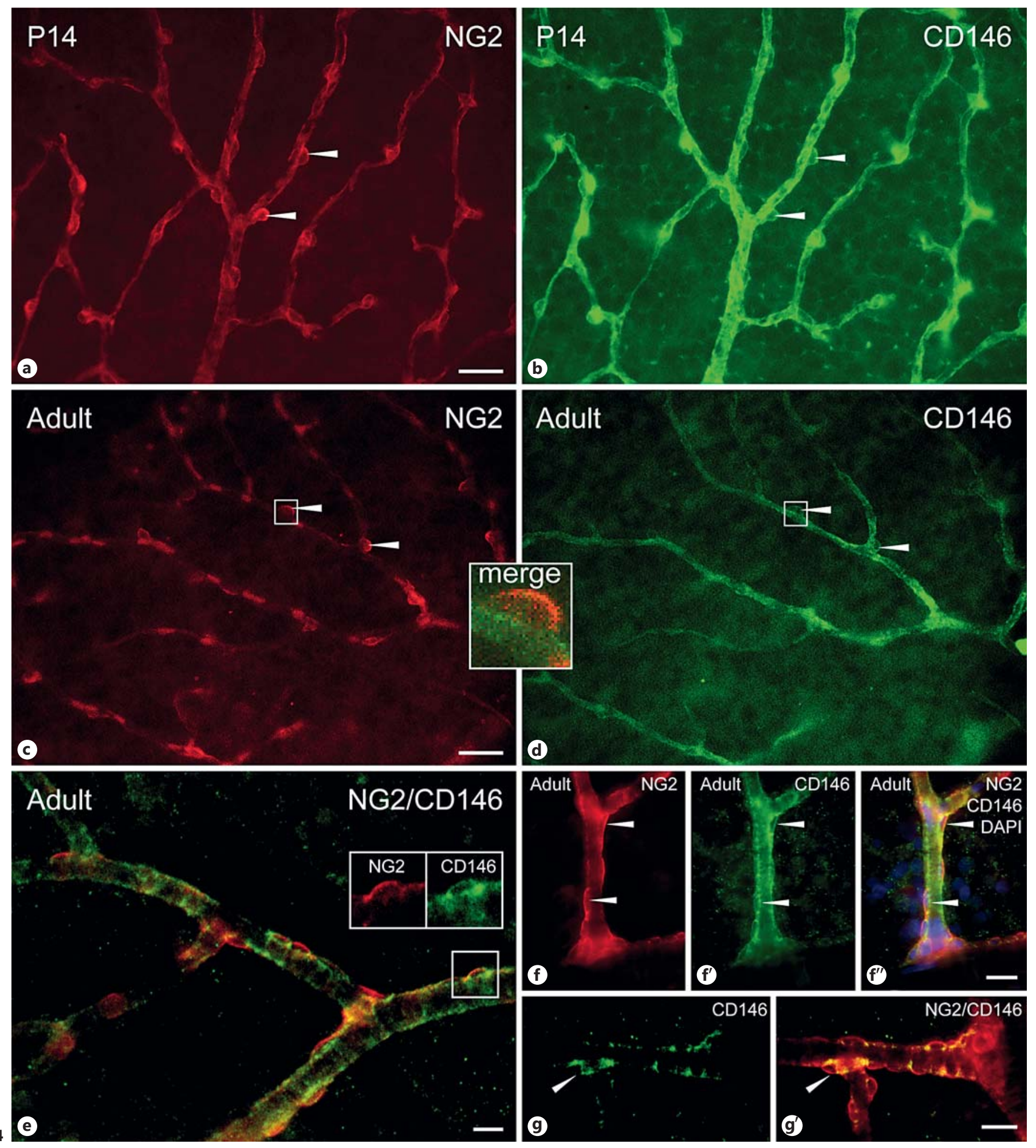


ing intensity for CD146 was modest. In rat retinal wholemount samples, a markedly similar distribution pattern was noted for both markers along the vessels (fig. 4 e, $\mathrm{f}, \mathrm{f}^{\prime}$, white arrowheads) in agreement with the observations made in the murine retina. Interestingly, CD146 reactivity around the retinal microvessels appeared to be stronger on the endothelial tube-neighbouring basal side and in branching processes of the labelled cells in contrast to NG2 reactivity that was mainly enriched in the plasma membrane of the cell body (please compare fig. 4e, insets). Another interesting observation was the appearance of intensely stained NG2/CD146-double positive cells located at small arteriole-to-capillary branching points (fig. 4g, $\mathrm{g}^{\prime}$, white arrowheads). In spite of the distinct subcellular localization and differences in staining intensity, a segregation of NG2 and CD146 in the pericytic cell population of capillaries could not be detected. Interestingly, however, in smooth muscle-like perivascular cells of arteriolar vessels with a larger diameter, although NG-2 positive, CD146 expression was very low/absent, as noted in the adult rat retina (data not shown). This is in line with the previously described phenotypic differences found between perivascular cells of capillaries and arteriolar vessels reflecting their distinct topographic and morphologic properties [Nehls and Drenckhahn, 1991].

\section{Expression of CD105 Is Restricted to Endothelial}

Tubes in Rodent Retinal Microvessels

In the following, we have analyzed the distribution of CD105, a frequently used surface marker for prospective isolation of MSCs [Haynesworth et al., 1992]. In double

Fig. 4. Confinement of the MSC marker CD146 to NG2-positive perivascular cells. Retinal cups isolated either from P14 (a, b) or adult $(\mathbf{c}, \mathbf{d})$ mice and that of adult rats $\left(\mathbf{e}-\mathbf{g}^{\prime}\right)$ were subjected to simultaneous IHC detection of NG2 (a, c, e, f, $\mathbf{f}^{\prime \prime}, \mathbf{g}^{\prime}$, red fluorescence) and CD146 (b, d, e, f, f'", g, g', green fluorescence) and compared in flat mounts. a-d Pairs of white arrowheads indicate NG2-positive perivascular cells (red) simultaneously expressing CD146 (green). a, b Note the intense labelling of perivascular cells for both markers and the high coverage of vessel tubes in 2-weekold retinae. c, $\mathbf{d}$ The boxed areas are displayed as a zoom-in merged image bridging both panels. e The boxed area is displayed as single channel zoom-in insets. $\mathbf{c}-\mathbf{g}^{\prime}$ Note the marked enrichment of NG2 reactivity in abluminal, pericytoplasmic plasmalemmal domains of perivascular cells both in adult mice (c/d, merged image) and rats (e, insets) and increased CD146 reactivity in abluminal membrane domains of the cell body and in branching processes around the vessel tube. g, g' Strong CD146 reactivity was detected in pericytic cells located at small arteriole-to-capillary branching points (white arrowhead). Scale bars $=25(\mathbf{a}-\mathbf{d}), 20(\mathbf{e}, \mathbf{g})$ and $10 \mu \mathrm{m}(\mathbf{f})$.

Putative MSCs in the Retinal Capillary Network immunolabelling experiments, pericytes were highlighted by anti-NG2 as described above and CD105 was detected in murine retinal samples by a well-characterised rat monoclonal antibody (MJ7/18) [Ge and Butcher, 1994], while in rat samples an anti-CD105 mouse monoclonal antibody was used [Bourdeau et al., 2001]. In murine retinal whole mounts obtained from juvenile and adult individuals, no co-localization was detected between NG2 and CD105 (fig. 5a, c: white arrowheads, b, d: white hollow arrowheads). An identical staining pattern was observed for CD105 in rat retina as revealed here in adult samples (fig. 5e-g). CD105 reactivity was exclusively confined to endothelial cells (fig. 5e: red fluorescence) outlining the network of endothelial tubes (fig. 5b, d, f), while NG2 reactivity was confined to abluminal pericytic cells of the vessel wall as described above (fig. $5 \mathrm{a} / \mathrm{b}, \mathrm{c} / \mathrm{d}$, f/g merged images: red fluorescence).

\section{Detection of Sox2, a Fate Determinant of Primitive} Embryonic and Neural Stem Cells, in Cryosections of P14 Retina

Next, we analyzed if resting vascular wall cells might express fate determinants of pluripotent primitive stem cells. Sox 2 is one of the major molecular determinants of embryonic pluripotent and neural stem cells. Molecularly, it is an SRY (Sox)-containing transcription factor [Chambers and Tomlinson, 2009]. Its transcripts were recently detected also in subpopulations of bone marrowderived non-haematopoietic MSCs [Tormin et al., 2011]. Applying a specific monoclonal antibody, cryosections of juvenile mice were analyzed (fig. 6). In order to facilitate the identification of distinct structures, nuclear counterstaining was performed with DAPI (fig. 6b). At P14, Sox2 reactivity was confined mainly to cell nuclei located within the ganglion cell layer harbouring nuclei of ganglion cells and those of displaced amacrine cells (fig. 6a, white hollow arrowheads). No confinement of Sox 2 reactivity was noted to any perivascular cell.

\section{Expression of NG2 and CD105 in Retina-Derived MSC-Like Cells in vitro}

Our above in situ data indicated that NG2-positive perivascular cells did not express CD105 in situ. Next, we have tested if in vitro cultivation would alter the phenotypic repertoire of NG2-expressing cells. To that end, dissociated retinal cells from adult mice were cultured over a period of 3 weeks on plastic according to established methods of pericyte isolation [Scheef et al., 2009; Tigges et al., 2012]. Morphologically, these cultured retina-derived cells in vitro were strongly reminiscent of arche- 


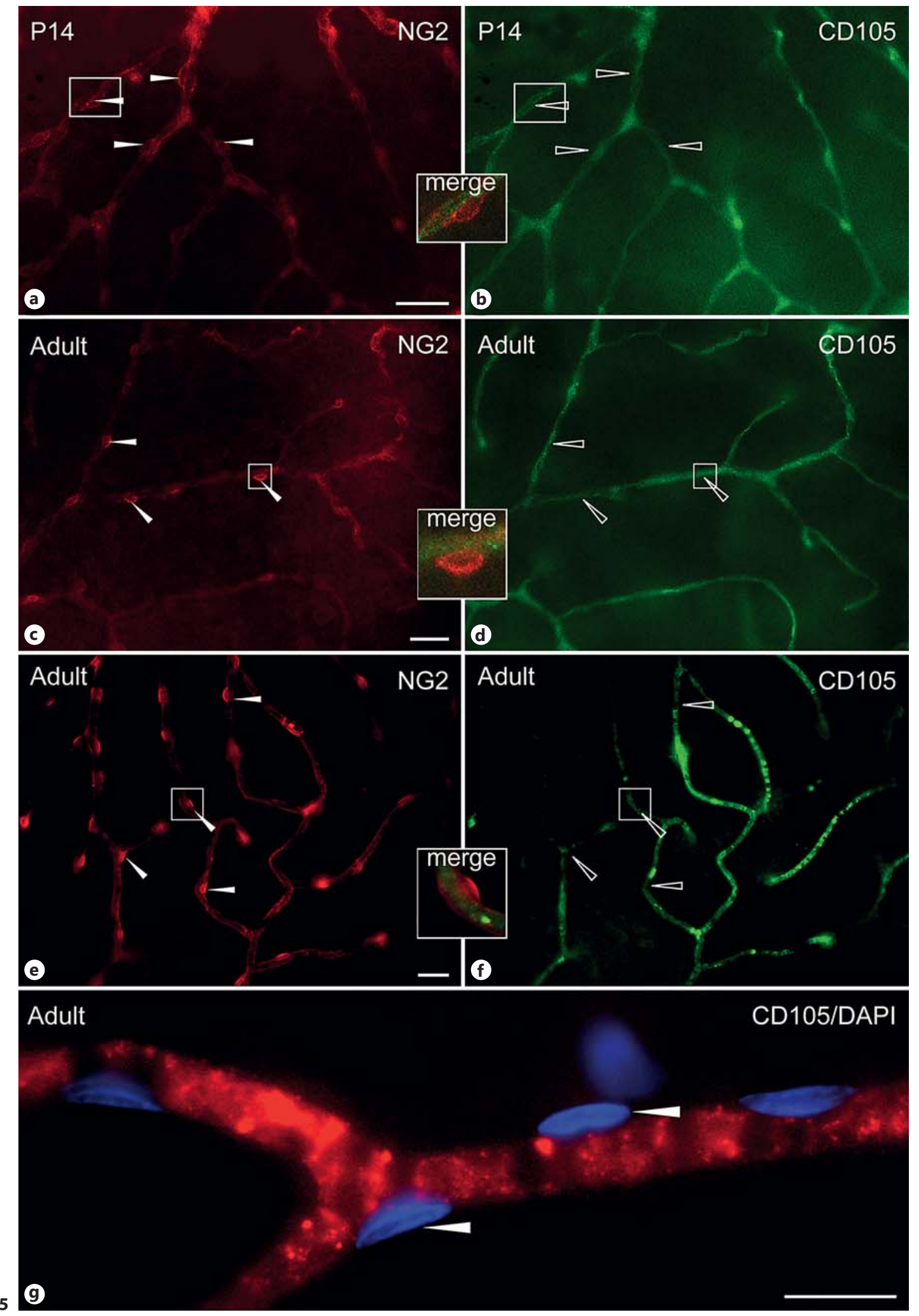


typal plastic-adherent stromal cells (MSCs) with the applied culture conditions. Double immunocytochemical detection of NG2 and CD105 revealed the simultaneous presence of both markers on a subpopulation of plasticadherent retinal cells. About one half of all cultured plastic-adherent cells were NG2 positive (56.2\%), CD105 was expressed by about two thirds of the adherent cells (70.1\%) and one third of all cells expressed neither of these markers (online suppl. fig. 3). More importantly, all of the NG2-positive cells expressed CD105 at the same time (fig. 7). The distribution of the two markers, however, is slightly distinct at the subcellullar level, i.e. NG2 is often absent in peripheral protrusions of plastic-adherent cells (fig. 7).

\section{Discussion}

The present study essentially reports the following major findings: (1) In juvenile rodent retina, not only the density of the retinal vascular network but also its coverage by mural cells is higher in comparison to the adult retinal vasculature. (2) Expression of CD146, one of the most extensively used surface markers of MSCs, highlights pericytic cells around the superficial retinal vascular plexus. (3) MSC-like pericytic cells are devoid of CD105 expression. (4) Sox2, a fate determinant characteristic of pluripotent primitive cells, is not detected in vascular cells of the retina. (5) In contrast to cells of the perivascular compartment in situ, a subpopulation of dispersed retina-derived plastic-adherent cells in vitro simultaneously expressed both NG2 and CD105.

\section{Retinal Microvasculature}

Our results show a distinct distribution pattern of perivascular NG2-positive cells around the retinal mi-

Fig. 5. CD105 (endoglin) reactivity does not co-localise with NG2positive perivascular cells. Retinal cups isolated either from P14 (a, b) or adult $(\mathbf{c}, \mathbf{d})$ mice and that of adult rats $(\mathbf{e}-\mathbf{g})$ were subjected to simultaneous IHC detection of NG2 (a, c, e, red fluorescence) and CD105 (b, d, f, g, green fluorescence) and compared in flat mounts. a-e White arrowheads point to NG2-positive perivascular cells (red); white hollow arrowheads indicate the lack of CD105 reactivity therein. Note that CD105 immunoreactivity is confined to the endothelial tubes of the microvasculature (green). $\mathbf{a} / \mathbf{b}$, c/d The boxed areas are displayed as zoom-in merged images bridging $\mathbf{a} / \mathbf{b}$ and $\mathbf{c} / \mathbf{d}$, respectively, which show the endothelial tube identified by CD105 (green) labelling and the NG2-positive abluminal pericytes (red). No co-localization could be detected. Scale bars $=25(\mathbf{a}-\mathbf{d}), 20(\mathbf{e}, \mathbf{f})$ and $10 \mu \mathrm{m}(\mathbf{g})$.

Putative MSCs in the Retinal Capillary Network crovessels in postnatal and young adult rodents. The NG2-positive areas are larger and more confluent in P14 retinae than in young adults. We have regarded this change in pericytic coverage of microvessels as a sign of maturation in the capillary network, which progresses during the first weeks after birth in rat and mouse retinae. In mice, from P7 onward, the superficial capillaries start sprouting vertically to form first the deep and then the intermediate vascular plexus. At early postnatal stages, the endothelial tube network undergoes significant remodelling and the recruitment of pericytic cells lags behind vessel formation. The deep plexus, located in the outer plexiform layer, forms rapidly and reaches the retinal periphery at approximately $\mathrm{P} 12$, followed by the intermediate plexus in the inner plexiform layer between P12 and P15. By the end of the 3rd postnatal week, all three vascular layers are fully mature with multiple interconnecting vessels between layers [Stahl et al., 2010]. NG2 is a chondroitin sulphate proteoglycan expressed in the plasma membrane surface of arteriolar and capillary pericytes, whereas it is absent in venular pericytes [Schlingemann et al., 1990; Murfee et al., 2005; DiazFlores et al., 2009a]. The arteriolar part of the microvasculature and the capillaries has been described as the preferential site of the 'vascular niche' of progenitor and stem cells and also MSCs [Ergun et al., 2011]. Regarding the function of NG2, it has been shown that soluble NG2 promotes endothelial cell mobility and angiogenesis via engagement of galectin 3 and $\alpha_{3} \beta_{1}$ integrin [Fukushi et al., 2004; Diaz-Flores et al., 2009a].

\section{Mesenchymal Stem Cells}

It is well documented that stromal cells of the bone marrow are endowed with significant multi-lineage differentiation abilities [Pittenger et al., 1999]. Providing the appropriate cues, these cells are able to give rise to distinct types of differentiated progeny, especially to those derived from mesodermal lineages during normal ontogenesis (e.g. adipocytes, smooth muscle cells or chondrocytes) [Song and Tuan, 2004]. These multipotent MSCs are characterised by a combinatorial expression of a number of cell surface molecules that enables their identification and isolation [Chamberlain et al., 2007; Sorrentino et al., 2008].

One of the major findings of the present study is the in situ demonstration of the confinement of CD146 expression to pericytic cells in the retinal vascular plexus of rodents. This molecule was early on recognised as a panendothelial marker also expressed by smooth muscle and stromal cells [Bardin et al., 1996]. By now, CD146 is a 


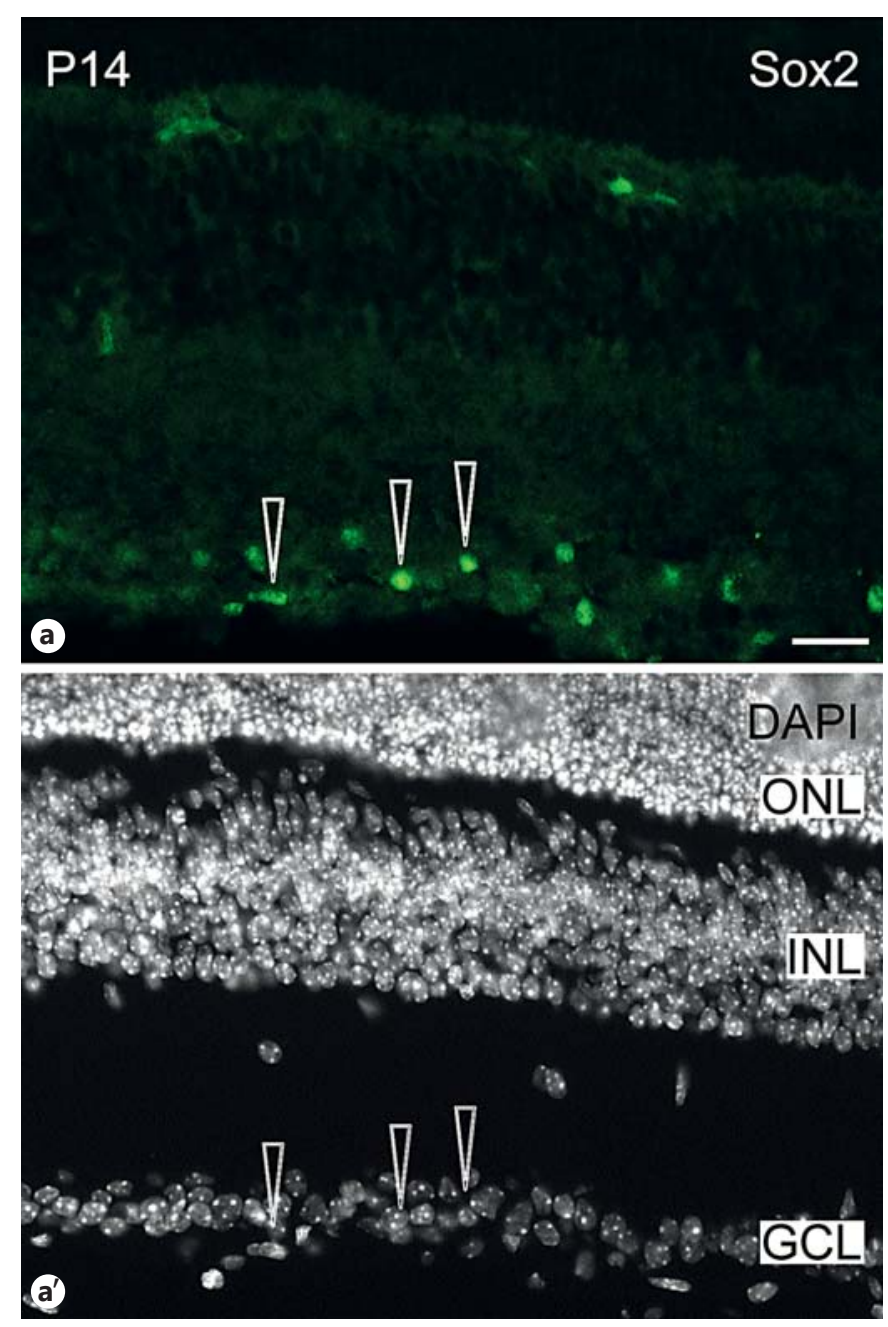

Fig. 6. Sox2, a marker and fate determinant of pluripotent cells, does not localise to the retinal vascular bed. Cryosections of P14 retinae were subjected to IHC detection of Sox2 (a). The nuclear architecture was revealed by DAPI counterstaining $\left(\mathbf{a}^{\prime}\right)$. Note that Sox2 immunoreactivity can be found in single dispersed nuclei within in the ganglion cell layer (GCL; a, white hollow arrows), while no labeling of vessel- or pericyte-like structures was detected. Scale bar $=25 \mu \mathrm{m}$. ONL/INL = Outer/inner nuclear layer.

widely used marker for the prospective isolation of nonhaematopoietic bone marrow stromal MSCs and MSClike cells isolated from multiple adult and fetal tissues. Interestingly, its expression has been linked to multipotency [Sacchetti et al., 2007; Covas et al., 2008; Crisan et al., 2008; Sorrentino et al., 2008; Tormin et al., 2011]. MSCs with greater differentiation potential express higher levels of CD146 on their cell surface [Russell et al., 2010]. Although CD146 is a widely used surface marker for isolating MSCs of various sources, the in vivo/in situ correlation of its expression with MSCs is only scarcely documented. Thus, expression of this marker was recently shown to define a subpopulation of subendothelial and perivascular stromal cells residing on the sinusoidal wall in the human bone marrow displaying mural cell properties in vitro [Sacchetti et al., 2007; Covas et al., 2008; Tormin et al., 2011], and its association with perivascular cells in certain human tissue was also demonstrated by Crisan et al. [2008].

Among other criteria, multipotent MSCs are characterised by the expression of the surface antigen CD105 [Haynesworth et al., 1992; Dominici et al., 2006]. CD105 (endoglin) is a homodimeric cell membrane glycoprotein of $180 \mathrm{kDa}$ [Gougos and Letarte, 1988] and is part of the TGF $\beta_{1}$ receptor complex [Fonsatti et al., 2001]. In contrast to perivascular cells isolated from various human tissues [Crisan et al., 2008], these cells of rodent retinal capillary networks, as we revealed here, were devoid of CD105. This is in line with previous reports indicating abundant expression of this molecule by vascular endothelial cells [St-Jacques et al., 1994; Fleming et al., 1998; Fonsatti et al., 2001]. Nevertheless, NG2-expressing plastic-adherent cell populations derived from dissociated murine retinal cultures could express both markers simultaneously in vitro. These findings indicate that in vivo the environment might have a suppressive effect on the expression of CD105 in NG2-positive perivascular cells that is relieved ex vivo. Whether it hints at a de-differentiated state of the NG2-positive perivascular cells in vitro will require further experimental effort.

In addition to the well-established role of Sox 2 in maintaining the pluripotent state of embryonic stem cells [Chambers and Tomlinson, 2009] during development, Sox 2 expression universally marks neural stem and progenitor cells throughout the CNS including the neural retina [Ellis et al., 2004]. Its expression is also detected in adult neural stem cells [Ellis et al., 2004; Episkopou, 2005]. Recently, expression of Sox 2 transcripts, along with other pluripotency markers, was also revealed in a subpopulation of isolated MSCs of bone marrow origin [Tormin et al., 2011]. In the present study, we could not detect an association of Sox 2 with pericytes. Whether this hints at the distinct origin of mesoderm-derived bone marrow perivascular cells and those of ectomesenchyme-derived cephalic ones or whether it is an indicator of a limited potency of the latter cells requires further elucidation. Nevertheless, in line with its role in neural retinal development and disorders, this molecule was found to be associated with the ganglion cell layer, as revealed here for the juvenile murine retina. Sox 2 was previously reported as a 


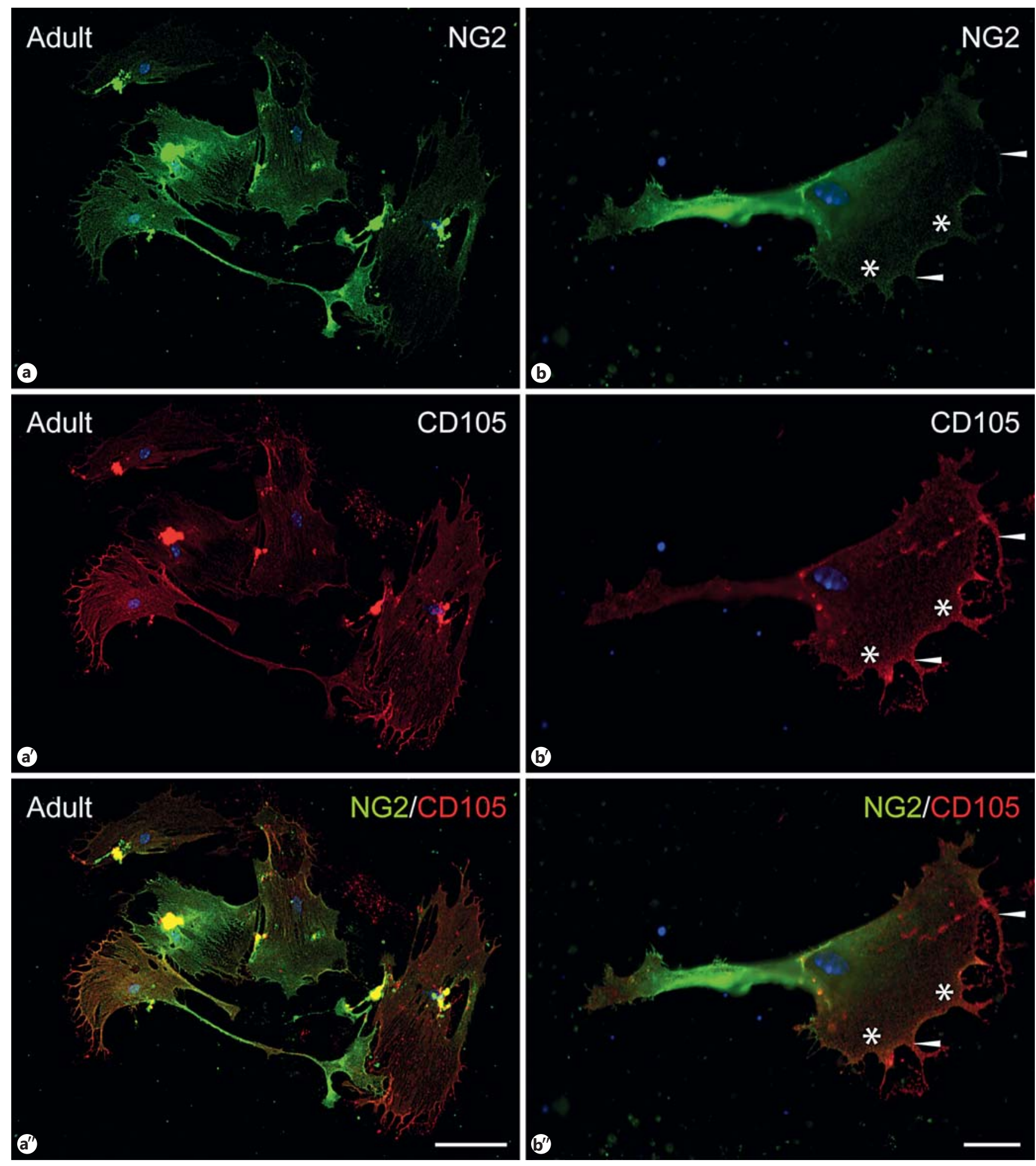

Fig. 7. Simultaneous expression of NG2 and CD105 on plasticadherent cells obtained from cultures of dissociated murine retina. Plastic-adherent cells were subjected to immunocytochemical detection of NG2 (a, b, green fluorescence) and CD105 ( $\mathbf{a}^{\prime}, \mathbf{b}^{\prime}$, red fluorescence) after a 3-week cultivation period. Apparently all NG2-positive cells simultaneously express CD105 (a', $\left.\mathbf{b}^{\prime}\right)$. The la-

belling intensity of both markers, however, varies from cell to cell $\left(\mathbf{a}-\mathbf{a}^{\prime \prime}\right)$. Note the distinct distribution of the two markers over the cell (b-b"). In contrast to CD105, which is rather homogenously distributed including 29 cellular protrusions (b', b', arrowheads), NG2 is often absent from the periphery of the cell (white asterisks). Scale bars $=100\left(\mathbf{a}-\mathbf{a}^{\prime \prime}\right)$ and $10 \mu \mathrm{m}\left(\mathbf{b}-\mathbf{b}^{\prime \prime}\right)$. 
dose-dependent regulator of retinal neural progenitor competence [Taranova et al., 2006] playing also a role in the induction of amacrine and Müller glial cells in mouse retinal progenitor cells [Lin et al., 2009]. Moreover, an association between mutations in the human gene and microphthalmia as well as anophthalmia was recently established [Schneider et al., 2009].

The potential therapeutic application of these multipotent cells is extensively studied in several paradigms. The presence of MSCs or MSC-like cells has been described in the interstitium of several (parenchymal) organs and their likely contribution to the endogenous regenerative processes is documented in postnatal and adult organisms [Crisan et al., 2008, 2009; Feng et al., 2011]. In many cases, however, the exact origin of such MSCs within a particular tissue is not resolved or documented [Feng et al., 2011; Tormin et al., 2011].

\section{'Vascular Niche'}

In a broader sense, the 'vascular niche' is a site especially rich in blood vessels where endothelial and mural cells (pericytes and smooth muscle cells) offer a microenvironment that supports the function of stem and progenitor cells [Palmer et al., 2000; Carmeliet, 2003; Nikolova and Lammert, 2003; Shen et al., 2008]. In neural tissues (e.g. in the subventricular plexus), stem cells can directly contact the vessels where they lack astrocyte endfeet or pericyte coverage [Tavazoie et al., 2008]. In the present study, apparently all NG2-positive cells in capillaries coincidently expressed CD146. At small arterioleto-capillary branching points, more intensely stained CD146-positive cells were located than in the linear (unbranched) sections. Further studies are required to determine whether this in turn reflects a greater differentiation potential of these particular cells [Russell et al., 2010].

Our findings are in favour of the hypothesis that the majority of all resting pericytes identified by CD146 along capillary vessels might belong to a potential MSC-like pool, as recently put forward by Caplan [2008] who considered all MSCs as if they were pericytes. The perivascular niche for the MSCs has been suggested as a specialised form of the vascular niche by several authors [Diaz-Flores et al., 1991; Nehls et al., 1992; Diaz-Flores et al., 2009; Kang et al., 2010]. In the human bone marrow niche, expression of CD146 distinguishes two MSC subpopulations. Therein, stromal cells that are subendothelial (perisinusoidal) highly express CD146, while the bone-lining endosteally localised stromal cells are CD146 negative [Sacchetti et al., 2007; Tormin et al., 2011].
Recent studies indicate that in several organs and tissues the microvasculature wall might represent a specialised cell compartment very similar to the bone marrow stromal compartment [Crisan et al., 2008]. Isolated mural cells of the brain and other organs show signs of multilineage differentiation like MSCs of the bone marrow do [Dore-Duffy et al., 2006; Crisan et al., 2008; Kang et al., 2010]. The novel role of the widespread microvascular network as a likely source of multipotent cells adds an additional layer of complexity to its classical role in homeostatic maintenance of tissues/organs as well as in regenerative processes. Lineage tracing experiments revealed that pericytes can be activated to act as MSCs and the relative contribution of pericyte-derived MSCs over nonpericyte-derived MSCs to cell differentiation in a given tissue or organ might depend on the extent of vascularity, as revealed in the dental pulp of growing and regenerating rodent incisors [Feng et al., 2011]. Based on their CD146 expression, the pericytic compartment of the mouse and rat retinal vessels might represent a potential source of MSC-like cells.

\section{Clinical Implications}

MSCs are attractive candidates for cell-based neuroprotective therapies in neurodegenerative diseases. After transplantation in situ, they produce and secrete a battery of both neurotrophic factors and anti-inflammatory cytokines [Kassis et al., 2011]. Secretion of these factors has been shown to confer strong neuroprotective effects in models of neurodegenerative diseases, including amyotrophic lateral sclerosis, multiple system atrophy, Parkinson's disease, multiple sclerosis, ischaemia and spinal cord injury [Karussis et al., 2008; Lee and Park, 2009; Park et al., 2010; Stemberger et al., 2011]. Successful cell therapy protocols have included local and systemic transplantation.

There is also experimental evidence that MSCs could exert a protective effect in the retina. MSCs transplanted into the vitreous cavity of rats after ischaemia and reperfusion [Li et al., 2009] or in an experimental model of glaucoma [Johnson et al., 2010] were proven to be neuroprotective.

\section{Conclusion}

The expression of the stem cell marker CD146 in the pericytic microvascular cell compartment in situ both in the murine and the rat retina hints at an MSC-like phenotypic trait of these cells that might contribute to a puta- 
tive retinal vessel stem cell niche, e.g. under pathologic conditions such as retinal neovascularization. Future functional studies are needed in order to assess the potential trans-differentiation capacity of CD146-positive retinal pericytes, their neuroprotective and immunomodulatory functions as well as their involvement in tissue repair and regeneration.

\section{Acknowledgments}

R.H.W.F. was supported by the Braun Stiftung, D.C. was supported by grants from the German Research Foundation (TRR83 No. 6; SFB655 B3 and CO298/5-1) and J.J. was supported by CO298/5-1. The authors wish to thank Claudia Müller for her excellent technical assistance in preparing samples for confocal laser scanning microscopy and Katrin Daniel for giving advice on imaging.

\section{References}

Anfosso, F., N. Bardin, E. Vivier, F. Sabatier, J. Sampol, F. Dignat-George (2001) Outside-in signaling pathway linked to CD146 engagement in human endothelial cells. J Biol Chem 276: $1564-1569$.

Bardin, N., F. George, M. Mutin, C. Brisson, N. Horschowski, V. Frances, G. Lesaule, J. Sampol (1996) S-Endo 1, a pan-endothelial monoclonal antibody recognizing a novel human endothelial antigen. Tissue Antigens 48: 531539.

Benjamin, L.E., I. Hemo, E. Keshet (1998) A plasticity window for blood vessel remodelling is defined by pericyte coverage of the preformed endothelial network and is regulated by PDGF-B and VEGF. Development 125: 15911598.

Bourdeau, A., M.E. Faughnan, M.L. McDonald, A.D. Paterson, I.R. Wanless, M. Letarte (2001) Potential role of modifier genes influencing transforming growth factor- $\beta 1$ levels in the development of vascular defects in endoglin heterozygous mice with hereditary hemorrhagic telangiectasia. Am J Pathol 158: 2011 2020.

Caplan, A.I. (2008) All MSCs are pericytes? Cell Stem Cell 3: 229-230.

-Carmeliet, P. (2003) Blood vessels and nerves: common signals, pathways and diseases. Nat Rev Genet 4: 710-720.

-Chamberlain, G., J. Fox, B. Ashton, J. Middleton (2007) Concise review: mesenchymal stem cells: their phenotype, differentiation capacity, immunological features, and potential for homing. Stem Cells 25: 2739-2749.

Chambers, I., S.R. Tomlinson (2009) The transcriptional foundation of pluripotency. Development 136: 2311-2322.

Chen, C.W., E. Montelatici, M. Crisan, M. Corselli, J. Huard, L. Lazzari, B. Peault (2009) Perivascular multi-lineage progenitor cells in human organs: regenerative units, cytokine sources or both? Cytokine Growth Factor Rev 20: 429-434.

Cogan, D.G., T. Kuwabara (1967) The mural cell in perspective. Arch Ophthalmol 78: 133139.

\begin{abstract}
Covas, D.T., R.A. Panepucci, A.M. Fontes, W.A. Silva, Jr., M.D. Orellana, M.C. Freitas, L. Neder, A.R. Santos, L.C. Peres, M.C. Jamur, M.A. Zago (2008) Multipotent mesenchymal stromal cells obtained from diverse human tissues share functional properties and gene-expression profile with CD146+ perivascular cells and fibroblasts. Exp Hematol 36: 642-654.

Crisan, M., C.W. Chen, M. Corselli, G. Andriolo, L. Lazzari, B. Peault (2009) Perivascular multipotent progenitor cells in human organs. Ann NY Acad Sci 1176: 118-123.
\end{abstract}

Crisan, M., S. Yap, L. Casteilla, C.W. Chen, M. Corselli, T.S. Park, G. Andriolo, B. Sun, B. Zheng, L. Zhang, C. Norotte, P.N. Teng, J. Traas, R. Schugar, B.M. Deasy, S. Badylak, H.J. Buhring, J.P. Giacobino, L. Lazzari, J. Huard, B. Peault (2008) A perivascular origin for mesenchymal stem cells in multiple human organs. Cell Stem Cell 3: 301-313.

Diaz-Flores, L., R. Gutierrez, J.F. Madrid, H. Varela, F. Valladares, E. Acosta, P. MartinVasallo, L. Diaz-Flores, Jr. (2009a) Pericytes. Morphofunction, interactions and pathology in a quiescent and activated mesenchymal cell niche. Histol Histopathol 24: 909-969.

-Diaz-Flores, L., R. Gutierrez, H. Varela, N. Rancel, F. Valladares (1991) Microvascular pericytes: a review of their morphological and functional characteristics. Histol Histopathol 6: 269-286.

Diaz-Flores, L., Jr., R. Gutierrez, J.F. Madrid, H. Varela, F. Valladares, L. Diaz-Flores (2009b) Adult stem cells and repair through granulation tissue. Front Biosci 14: 1433-1470.

Dominici, M., K. Le Blanc, I. Mueller, I. SlaperCortenbach, F. Marini, D. Krause, R. Deans, A. Keating, D. Prockop, E. Horwitz (2006) Minimal criteria for defining multipotent mesenchymal stromal cells. The International Society for Cellular Therapy position statement. Cytotherapy 8: 315-317.

Dore-Duffy, P., A. Katychev, X. Wang, E. Van Buren (2006) CNS microvascular pericytes exhibit multipotential stem cell activity. J Cereb Blood Flow Metab 26: 613-624.

-Ejaz, S., I. Chekarova, A. Ejaz, A. Sohail, C.W. Lim (2008) Importance of pericytes and mechanisms of pericyte loss during diabetes retinopathy. Diabetes Obes Metab 10: 53-63.
Ellis, P., B.M. Fagan, S.T. Magness, S. Hutton, O. Taranova, S. Hayashi, A. McMahon, M. Rao, L. Pevny (2004) SOX2, a persistent marker for multipotential neural stem cells derived from embryonic stem cells, the embryo or the adult. Dev Neurosci 26: 148-165.

Episkopou, V. (2005) SOX2 functions in adult neural stem cells. Trends Neurosci 28: 219-221.

Ergun, S., D. Tilki, D. Klein (2011) Vascular wall as a reservoir for different types of stem and progenitor cells. Antioxid Redox Signal 15: 981-995.

Feit-Leichman, R.A., R. Kinouchi, M. Takeda, Z. Fan, S. Mohr, T.S. Kern, D.F. Chen (2005) Vascular damage in a mouse model of diabetic retinopathy: relation to neuronal and glial changes. Invest Ophthalmol Vis Sci 46: 4281-4287.

Feng, J., A. Mantesso, C. De Bari, A. Nishiyama, P.T. Sharpe (2011) Dual origin of mesenchymal stem cells contributing to organ growth and repair. Proc Natl Acad Sci USA 108: 6503-6508.

Fleming, J.E., Jr., S.E. Haynesworth, P. Cassiede, M.A. Baber, A.I. Caplan (1998) Monoclonal antibody against adult marrow-derived mesenchymal stem cells recognizes developing vasculature in embryonic human skin. Dev Dyn 212: 119-132.

Fonsatti, E., L. Del Vecchio, M. Altomonte, L. Sigalotti, M.R. Nicotra, S. Coral, P.G. Natali, M. Maio (2001) Endoglin: an accessory component of the TGF-beta-binding receptor-complex with diagnostic, prognostic, and bioimmunotherapeutic potential in human malignancies. J Cell Physiol 188: 1-7.

Fukushi, J., I.T. Makagiansar, W.B. Stallcup (2004) NG2 proteoglycan promotes endothelial cell motility and angiogenesis via engagement of galectin-3 and alpha3betal integrin. Mol Biol Cell 15: 3580-3590.

Funk, R. (1986) Studies on the functional morphology of rat ocular vessels with scanning electron microscopy. Acta Anat (Basel) 125: 252-257.

Funk, R.H. (1997) Blood supply of the retina. Ophthalmic Res 29: 320-325.

Ge, A.Z., E.C. Butcher (1994) Cloning and expression of a cDNA encoding mouse endoglin, an endothelial cell TGF-beta ligand. Gene 138: 201-206.
Putative MSCs in the Retinal Capillary Network
Cells Tissues Organs 2013;197:344-359 
Gerhardt, H., C. Betsholtz (2003) Endothelialpericyte interactions in angiogenesis. Cell Tissue Res 314: 15-23.

-Gougos, A., M. Letarte (1988) Identification of a human endothelial cell antigen with monoclonal antibody 44G4 produced against a preB leukemic cell line. J Immunol 141: 19251933.

Hammes, H.P. (2005) Pericytes and the pathogenesis of diabetic retinopathy. Horm Metab Res 37(suppl 1): 39-43.

Haynesworth, S.E., M.A. Baber, A.I. Caplan (1992) Cell surface antigens on human marrow-derived mesenchymal cells are detected by monoclonal antibodies. Bone 13: 69-80. Hirschi, K.K., P.A. D’Amore (1996) Pericytes in
the microvasculature. Cardiovasc Res 32: 687-698.

Ikesugi, K., M.L. Mulhern, C.J. Madson, K. Hosoya, T. Terasaki, P.F. Kador, T. Shinohara (2006) Induction of endoplasmic reticulum stress in retinal pericytes by glucose deprivation. Curr Eye Res 31: 947-953.

-Jaszai, J., L.M. Farkas, C.A. Fargeas, P. Janich, M. Haase, W.B. Huttner, D. Corbeil (2010) Prominin-2 is a novel marker of distal tubules and collecting ducts of the human and murine kidney. Histochem Cell Biol 133: 527-539.

Johnson, T.V., N.D. Bull, D.P. Hunt, N. Marina, S.I. Tomarev, K.R. Martin (2010) Neuroprotective effects of intravitreal mesenchymal stem cell transplantation in experimental glaucoma. Invest Ophthalmol Vis Sci 51: 2051-2059.

Kang, S.G., N. Shinojima, A. Hossain, J. Gumin, R.L. Yong, H. Colman, F. Marini, M. Andreeff, F.F. Lang (2010) Isolation and perivascular localization of mesenchymal stem cells from mouse brain. Neurosurgery 67: 711720 .

Karussis, D., I. Kassis, B.G. Kurkalli, S. Slavin (2008) Immunomodulation and neuroprotection with mesenchymal bone marrow stem cells (MSCs): a proposed treatment for multiple sclerosis and other neuroimmunological/neurodegenerative diseases. J Neurol Sci 265: 131-135.

-Kassis, I., A. Vaknin-Dembinsky, D. Karussis (2011) Bone marrow mesenchymal stem cells: agents of immunomodulation and neuroprotection. Curr Stem Cell Res Ther 6: 63-68.

Lee, P.H., H.J. Park (2009) Bone marrow-derived mesenchymal stem cell therapy as a candidate disease-modifying strategy in Parkinson's disease and multiple system atrophy. J Clin Neurol 5: 1-10.

Li, N., X.R. Li, J.Q. Yuan (2009) Effects of bonemarrow mesenchymal stem cells transplanted into vitreous cavity of rat injured by ischemia/ reperfusion. Graefes Arch Clin Exp Ophthalmol 247: 503-514.

Lin, Y.P., Y. Ouchi, S. Satoh, S. Watanabe (2009) Sox2 plays a role in the induction of amacrine and Muller glial cells in mouse retinal progenitor cells. Invest Ophthalmol Vis Sci 50: 6874.
Murfee, W.L., T.C. Skalak, S.M. Peirce (2005) Differential arterial/venous expression of NG2 proteoglycan in perivascular cells along microvessels: identifying a venule-specific phenotype. Microcirculation 12: 151-160.

Nehls, V., K. Denzer, D. Drenckhahn (1992) Pericyte involvement in capillary sprouting during angiogenesis in situ. Cell Tissue Res 270: 469-474.

Nehls, V., D. Drenckhahn (1991) Heterogeneity of microvascular pericytes for smooth muscle type alpha-actin. J Cell Biol 113: 147-154.

Nikolova, G., E. Lammert (2003) Interdependent development of blood vessels and organs. Cell Tissue Res 314: 33-42.

Ozerdem, U., E. Monosov, W.B. Stallcup (2002) NG2 proteoglycan expression by pericytes in pathological microvasculature. Microvasc Res 63: 129-134.

Palmer, T.D., A.R. Willhoite, F.H. Gage (2000) Vascular niche for adult hippocampal neurogenesis. J Comp Neurol 425: 479-494.

Park, H.J., G. Bang, B.R. Lee, H.O. Kim, P.H. Lee (2010) Neuroprotective effect of human mesenchymal stem cells in an animal model of double toxin-induced multiple system atrophy parkinsonism. Cell Transplant 20: 827835.

Peppiatt, C.M., C. Howarth, P. Mobbs, D. Attwell (2006) Bidirectional control of CNS capillary diameter by pericytes. Nature 443: 700-704.

Pittenger, M.F., A.M. Mackay, S.C. Beck, R.K. Jaiswal, R. Douglas, J.D. Mosca, M.A. Moorman, D.W. Simonetti, S. Craig, D.R. Marshak (1999) Multilineage potential of adult human mesenchymal stem cells. Science 284: 143147.

Russell, K.C., D.G. Phinney, M.R. Lacey, B.L. Barrilleaux, K.E. Meyertholen, K.C. O'Connor (2010) In vitro high-capacity assay to quantify the clonal heterogeneity in trilineage potential of mesenchymal stem cells reveals a complex hierarchy of lineage commitment. Stem Cells 28: 788-798.

Sacchetti, B., A. Funari, S. Michienzi, S. Di Cesare, S. Piersanti, I. Saggio, E. Tagliafico, S. Ferrari, P.G. Robey, M. Riminucci, P. Bianco (2007) Self-renewing osteoprogenitors in bone marrow sinusoids can organize a hematopoietic microenvironment. Cell 131: 324-336.

-Scheef, E.A., C.M. Sorenson, N. Sheibani (2009) Attenuation of proliferation and migration of retinal pericytes in the absence of thrombospondin-1. Am J Physiol Cell Physiol 296: C724-C734.

Schlingemann, R.O., F.J. Rietveld, R.M. de Waal, S. Ferrone, D.J. Ruiter (1990) Expression of the high molecular weight melanoma-associated antigen by pericytes during angiogenesis in tumors and in healing wounds. Am J Pathol 136: 1393-1405.

Schmidt, K.G., H. Bergert, R.H. Funk (2008) Neurodegenerative diseases of the retina and potential for protection and recovery. Curr Neuropharmacol 6: 164-178.
Schneider, A., T. Bardakjian, L.M. Reis, R.C. Tyler, E.V. Semina (2009) Novel SOX2 mutations and genotype-phenotype correlation in anophthalmia and microphthalmia. Am J Med Genet A 149A: 2706-2715.

-Schonfelder, U., A. Hofer, M. Paul, R.H. Funk (1998) In situ observation of living pericytes in rat retinal capillaries. Microvasc Res 56: 22-29.

Schrage, A., C. Loddenkemper, U. Erben, U. Lauer, G. Hausdorf, P.R. Jungblut, J. Johnson, P.A. Knolle, M. Zeitz, A. Hamann, K. Klugewitz (2008) Murine CD146 is widely expressed on endothelial cells and is recognized by the monoclonal antibody ME-9F1. Histochem Cell Biol 129: 441-451.

-Shen, Q., Y. Wang, E. Kokovay, G. Lin, S.M. Chuang, S.K. Goderie, B. Roysam, S. Temple (2008) Adult SVZ stem cells lie in a vascular niche: a quantitative analysis of niche cell-cell interactions. Cell Stem Cell 3: 289-300.

-Sims, D.E. (1991) Recent advances in pericyte biology - implications for health and disease. Can J Cardiol 7: 431-443.

Song, L., R.S. Tuan (2004) Transdifferentiation potential of human mesenchymal stem cells derived from bone marrow. FASEB J 18: 980 982.

Sorrentino, A., M. Ferracin, G. Castelli, M. Biffoni, G. Tomaselli, M. Baiocchi, A. Fatica, M. Negrini, C. Peschle, M. Valtieri (2008) Isolation and characterization of CD146+ multipotent mesenchymal stromal cells. Exp Hematol 36: 1035-1046.

St-Jacques, S., U. Cymerman, N. Pece, M. Letarte (1994) Molecular characterization and in situ localization of murine endoglin reveal that it is a transforming growth factor-beta binding protein of endothelial and stromal cells. Endocrinology 134: 2645-2657.

Stahl, A., K.M. Connor, P. Sapieha, J. Chen, R.J. Dennison, N.M. Krah, M.R. Seaward, K.L. Willett, C.M. Aderman, K.I. Guerin, J. Hua, C. Lofqvist, A. Hellstrom, L.E. Smith (2010) The mouse retina as an angiogenesis model. Invest Ophthalmol Vis Sci 51: 2813-2826.

-Stemberger, S., A. Jamnig, N. Stefanova, G. Lepperdinger, M. Reindl, G.K. Wenning (2011) Mesenchymal stem cells in a transgenic mouse model of multiple system atrophy: immunomodulation and neuroprotection. PLoS One 6: e19808.

Stewart, P.A., U.I. Tuor (1994) Blood-eye barriers in the rat: correlation of ultrastructure with function. J Comp Neurol 340: 566-576.

Taranova, O.V., S.T. Magness, B.M. Fagan, Y. $\mathrm{Wu}, \mathrm{N}$. Surzenko, S.R. Hutton, L.H. Pevny (2006) SOX2 is a dose-dependent regulator of retinal neural progenitor competence. Genes Dev 20: 1187-1202.

-Tavazoie, M., L. Van der Veken, V. Silva-Vargas, M. Louissaint, L. Colonna, B. Zaidi, J.M. Garcia-Verdugo, F. Doetsch (2008) A specialized vascular niche for adult neural stem cells. Cell Stem Cell 3: 279-288. 
Thanabalasundaram, G., C. Pieper, M. Lischper, H.J. Galla (2010) Regulation of the bloodbrain barrier integrity by pericytes via matrix metalloproteinases mediated activation of vascular endothelial growth factor in vitro. Brain Res 1347: 1-10.

- Tigges, U., J.V. Welser-Alves, A. Boroujerdi, R. Milner (2012) A novel and simple method for culturing pericytes from mouse brain. Microvasc Res 84: 74-80.

Tilki, D., H.P. Hohn, B. Ergun, S. Rafii, S. Ergun (2009) Emerging biology of vascular wall progenitor cells in health and disease. Trends Mol Med 15: 501-509.
Tilton, R.G., A.M. Faller, J.K. Burkhardt, P.L. Hoffmann, C. Kilo, J.R. Williamson (1985) Pericyte degeneration and acellular capillaries are increased in the feet of human diabetic patients. Diabetologia 28: 895-900.

Tormin, A., O. Li, J.C. Brune, S. Walsh, B. Schutz, M. Ehinger, N. Ditzel, M. Kassem, S. Scheding (2011) CD146 expression on primary nonhematopoietic bone marrow stem cells is correlated with in situ localization. Blood 117: 5067-5077.

Verbeek, M.M., R.M. de Waal, J.J. Schipper, W.E. Van Nostrand (1997) Rapid degeneration of cultured human brain pericytes by amyloid beta protein. J Neurochem 68: 1135-1141.
Verbeek, M.M., I. Otte-Holler, D.J. Ruiter, R.M. de Waal (1999) Human brain pericytes as a model system to study the pathogenesis of cerebrovascular amyloidosis in Alzheimer's disease. Cell Mol Biol (Noisy-le-grand) 45: 37-46.

Witmer, A.N., B.C. van Blijswijk, C.J. van Noorden, G.F. Vrensen, R.O. Schlingemann (2004) In vivo angiogenic phenotype of endothelial cells and pericytes induced by vascular endothelial growth factor-A. J Histochem Cytochem 52: 39-52.

Zlokovic, B.V. (2008) The blood-brain barrier in health and chronic neurodegenerative disorders. Neuron 57: 178-201. 